\title{
Understanding competition between healthcare providers: Introducing an intermediary inter- organizational perspective
}

Citation for published version (APA):

Westra, D., Angeli, F., Carree, M., \& Ruwaard, D. (2017). Understanding competition between healthcare providers: Introducing an intermediary inter-organizational perspective. Health Policy, 121(2), 149-157. https://doi.org/10.1016/j.healthpol.2016.11.018

Document status and date:

Published: 01/02/2017

DOI:

10.1016/j.healthpol.2016.11.018

Document Version:

Publisher's PDF, also known as Version of record

\section{Document license:}

Taverne

Please check the document version of this publication:

- A submitted manuscript is the version of the article upon submission and before peer-review. There can be important differences between the submitted version and the official published version of record.

People interested in the research are advised to contact the author for the final version of the publication, or visit the DOI to the publisher's website.

- The final author version and the galley proof are versions of the publication after peer review.

- The final published version features the final layout of the paper including the volume, issue and page numbers.

Link to publication

\footnotetext{
General rights rights.

- You may freely distribute the URL identifying the publication in the public portal. please follow below link for the End User Agreement:

www.umlib.nl/taverne-license

Take down policy

If you believe that this document breaches copyright please contact us at:

repository@maastrichtuniversity.nl

providing details and we will investigate your claim.
}

Copyright and moral rights for the publications made accessible in the public portal are retained by the authors and/or other copyright owners and it is a condition of accessing publications that users recognise and abide by the legal requirements associated with these

- Users may download and print one copy of any publication from the public portal for the purpose of private study or research.

- You may not further distribute the material or use it for any profit-making activity or commercial gain

If the publication is distributed under the terms of Article $25 \mathrm{fa}$ of the Dutch Copyright Act, indicated by the "Taverne" license above, 


\title{
Understanding competition between healthcare providers: Introducing an intermediary inter-organizational perspective
}

\author{
Daan Westra ${ }^{\mathrm{a}, *}$, Federica Angeli $^{\mathrm{a}}$, Martin Carree ${ }^{\mathrm{b}}$, Dirk Ruwaard $^{\mathrm{a}}$ \\ a Department of Health Services Research, Faculty of Health, Medicine and Life Sciences, Maastricht University, Maastricht, The \\ Netherlands \\ b Department of Organisation and Strategy, School of Business and Economics, Maastricht University, Maastricht, The Netherlands
}

\section{A R T I C L E I N F O}

\section{Article history:}

Received 24 August 2015

Received in revised form

15 November 2016

Accepted 23 November 2016

\section{Keywords:}

Pro-competitive reform

Managed competition

Inter-organizational networks

Inter-organizational cooperation

Market structure

Health outcomes

\begin{abstract}
A B S T R A C T
Pro-competitive policy reforms have been introduced in several countries, attempting to contain increasing healthcare costs. Yet, research proves ambiguous when it comes to the effect of competition in healthcare, with a number of studies highlighting unintended and unwanted effects. We argue that current empirical work overlooks the role of inter-organizational relations as well as the interplay between policy at macro level, interorganizational networks at meso level, and outcomes at micro level. To bridge this gap and stimulate a more detailed understanding of the effect of competition in health care, this article introduces a cross-level conceptual framework which emphasizes the intermediary role of cooperative inter-organizational relations at meso level. We discuss how patient transfers, specialist affiliations, and interlocking directorates constitute three forms of inter-organizational relations in health care which can be used within this framework. The paper concludes by deriving several propositions from the framework which can guide future research.
\end{abstract}

(c) 2016 Elsevier Ireland Ltd. All rights reserved.

\section{Introduction}

Rising healthcare expenditures [1], demographic challenges, and technological advancements compel nations to find appropriate ways to organise their healthcare systems [2]. Policymakers face the challenge to control health expenditures at the macro level while incentivising efficiency at the micro level [3]. Between the 1970s and the 1990s regulated systems were the most common way for Western countries to organise their healthcare sector [4,5]. Although they were able to control macro-level health

\footnotetext{
* Corresponding author.

E-mail addresses: d.westra@maastrichtuniversity.nl

(D. Westra), federica.angeli@maastrichtuniversity.nl

(F. Angeli), m.carree@maastrichtuniversity.nl (M. Carree),

d.ruwaard@maastrichtuniversity.nl (D. Ruwaard).
}

expenditures, these systems were burdened by imbalanced supply and demand and a lack of efficiency stimuli [2,5]. Several countries consequently introduced legislation spurring competition within their healthcare system in an attempt to stimulate efficient healthcare delivery and resource allocation [2,5-9]. Yet, competition in health care is controversial topic and its potential adverse effects have left some policymakers hesitant to introduce procompetitive reforms [6].

In health care markets competition is often referred to as 'managed competition' which is defined as a set of 'rules for competition' between care providers designed to obtain maximum value for money [10]. Value is the best possible health outcomes achieved per dollar spent, which is what ultimately matters for patients and society [11]. Competition can furthermore occur between third-party purchasers such as insurers who compete for enrolees 
or between healthcare providers (i.e. organizations) who compete to be (selectively) contracted by purchasers $[12,13]$. In this paper we refer to the latter. Supporters of competition argue that it stimulates providers to seek a competitive advantage over each other, which boosts efficiency and ultimately benefits patients $[12,14,15]$. However, antagonists argue that the characteristics of health care render competition in the sector ineffective [16].

Empirical studies regarding the impact of competition on health outcomes have produced positive as well as negative results in price-competitive as well as non-price competitive systems (i.e. systems where prices are regulated or pre-determined) $[17,18]$. In price-competitive systems like the United States or The Netherlands purchasers selectively contract services from providers based on freely negotiable treatment prices $[13,19]$. The theoretical prediction that this drives down treatment price is supported by several empirical findings [e.g. 20-22]. But findings regarding the effect of price competition on various indicators of quality of care are mixed. Some studies find that it increases quality [e.g. 23,24-26] while others display opposing or no significant effects [e.g. 27,28]. In non-price-competitive systems on the other hand, quality is the primary differentiating factor for providers, which can result in a so-called 'Medical Arms Race' (MAR) [29]. The theoretical prediction that this increases overall health expenditures $[13,30]$ is supported by several empirical findings [e.g. 31,32,33], while findings concerning the effect of non-price competition on indicators of quality of care are also mixed [24,34-41].

Most of these empirical studies have been rooted in the traditional neoclassical perception of competition. It assumes that outcomes are a result of an industry's structural characteristics which influence rivalry and organizational behaviour $[42,43]$. The Structure-ConductPerformance (SCP) paradigm, in which market structure (e.g. concentration) is associated with outcomes, has hence served as the primary empirical approach. However, the approach is typically applied in a cross-sectional way to analyse markets in an equilibrium, whereas healthcare reform is an inherently dynamic and ongoing process $[44,45]$ that makes markets unstable and changing. It has furthermore been criticized for overlooking organizational behaviour in empirical testing $[46,47]$ and inter-organizational cooperation has been explicitly described as difficult to capture within the traditional competitive paradigm [48]. The dynamic nature and failure to account for inter-organizational behaviour could very well explain the mixed findings of empirical research. As a result, our understanding of the effectiveness of competition in healthcare settings remains limited and a conclusive answer to the question whether policymakers should or should not introduce pro-competitive reforms to improve value for patients is lacking.

In order to foster a more detailed understanding of competition in healthcare markets, some researchers have suggested that the institutional context (i.e. macro level), behavioural features of healthcare providers (i.e. meso level), and health outcomes (i.e. micro levels) should be considered simultaneously when analysing healthcare reforms [49,50]. Scant academic attention has however been paid to the complex interplay between the policy (macro), inter-organizational (meso), and outcome (micro) levels. This paper aims to advance the understanding of the interplay between these levels. It does so by formalizing a conceptual framework that can support future research regarding the role and evolution of cooperative inter-organizational relations between healthcare organizations as intermediary between policy reforms and health outcomes.

\section{Theoretical approach}

We have conducted a narrative review of academic literature regarding (1) the relation between macro level reforms and meso level healthcare markets, (2) the meso level healthcare market and health outcomes, (3) the role of cooperative inter-organizational relations between healthcare providers in determining health outcomes, (4) how inter-organizational relations form networks of healthcare providers, and (5) the types of inter-organizational relations which exist in health care. We have synthesized the findings from these bodies of literature by formalizing a cross-level conceptual framework (see Fig. 1). The framework highlights the interplay between macro level policy reforms, meso level healthcare markets, and micro level outcomes. At the meso level, the role of interorganizational relations between healthcare organizations is emphasized. The framework seeks to facilitate research regarding the effect of pro-competitive policy reforms on patient level outcomes within the healthcare domain. In order to guide such future research, several testable propositions have been derived from this framework.

\section{Results from the literature review}

\subsection{The need for an inter-organizational network perspective to health care}

Despite the fact that the neoclassical rules of competition have been well-established, many scholars have also recognized the fact that cooperative inter-organizational relations between independent autonomous organizations are essential to an organization's goal attainment [51]. This notion has for example been formalized in concepts such as the relational view (RV), which proposes that dyads of organizations create additional value through sharing knowledge and utilizing complementary resources [e.g. 52,53], 'coopetition', which refers to the simultaneous cooperation and competition between organizations [e.g. 54,55], and strategic networks, defined as purposeful longterm relations between separate organizations to pursue a competitive advantage [e.g. 48].

Although it was not specified as a differential factor by Arrow [16] in his influential work on the differences between the healthcare industry and other industries, much of the initial work regarding cooperative interorganizational relations has stemmed from non-profit and specifically the healthcare industry [e.g. 51,56]. The nonprofit nature of the industries in which inter-organizational relations were commonly discussed initially led strategy scholars to pay little attention to the concept [48]. However, 


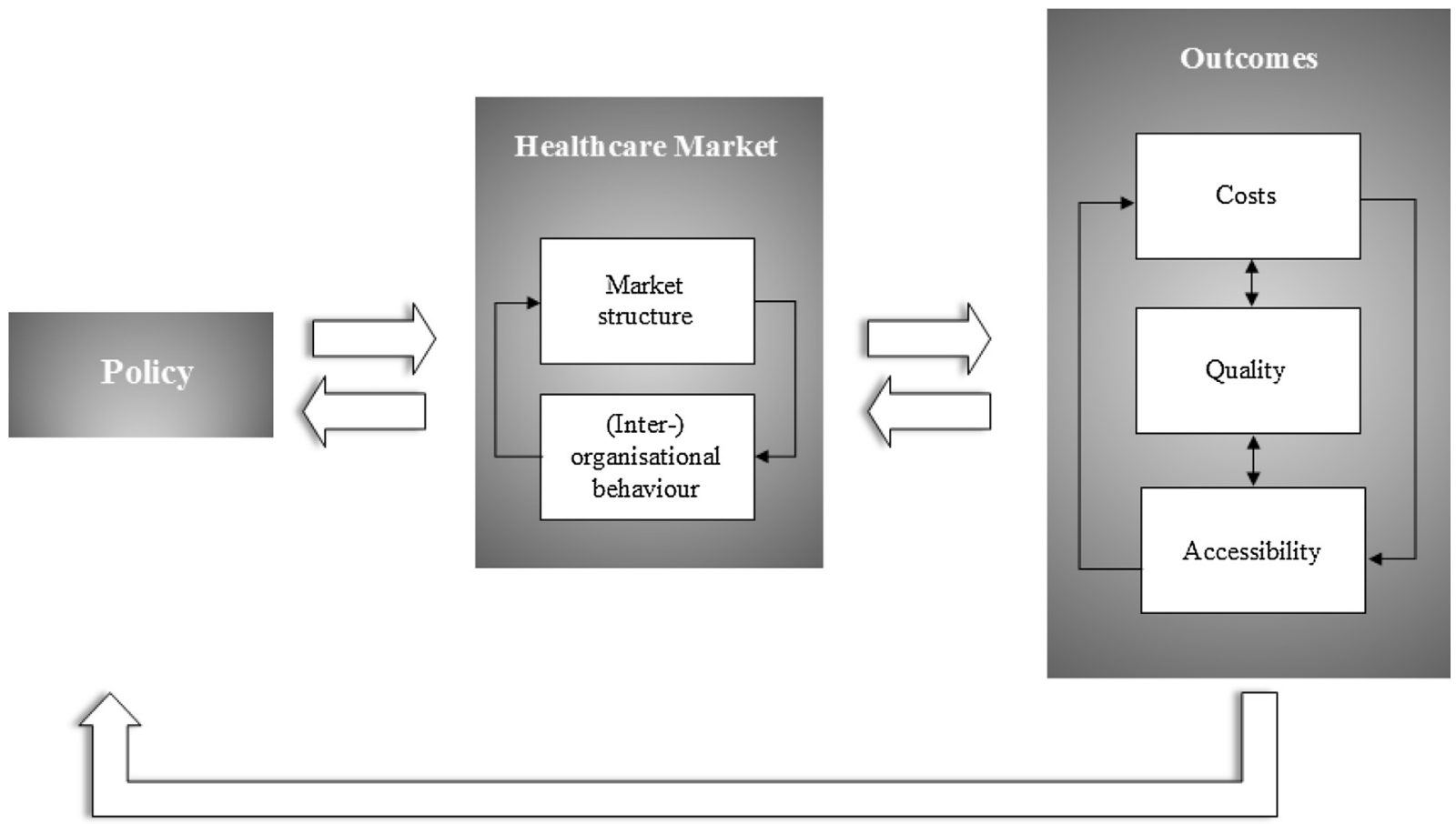

Macro Level

Meso Level

Micro Level

Fig. 1. Cross-level conceptual framework.

inter-organizational relations have long been established as a relevant mechanism for and determinant of efficient and effective healthcare delivery $[57,58]$. This crucial role of inter-organizational relations within the healthcare domain primarily stems from healthcare's fragmented nature and (increasing) sub-specialization [59,60]. In fact, scholars have widely recognized that health care is a service which is delivered by several cooperating providers $[58,61,62]$, implying that even for a single disease, a patient is typically treated by more than one organization. In 1984 for example, Provan [63] wrote that 'most hospitals form collaborative agreements with other healthcare organizations'. Fostering and sustaining successful inter-organizational collaboration between healthcare providers has subsequently been, and continues to be, a focal point of research within the industry [e.g. 61,64].

While the non-profit environment of many healthcare industries is what has arguably enabled cooperative inter-organizational relations to flourish, pro-competitive reforms have greatly altered the context of the healthcare industry in several Western countries. In any industry a firm's performance cannot be fully understood without considering the inter-organizational relations in which it is embedded [65]. We argue that overlooking interorganizational relations in health care, an industry in which they are widespread, generates an incomplete understanding of the effects of pro-competitive reforms. In order to better understand whether pro-competitive reforms positively affect health outcomes, research should thus consider (changes in) such inter-organizational relations between healthcare organizations. The consideration should furthermore transcend the dyadic level (i.e. as a relation between organization $A$ and organization $B$ ) because that disregards the embeddedness of such relations in a larger social context [66]. The collection of inter-organizational relations between a group of organizations together comprise a 'whole' network [52,58] and should instead be considered as such.

The term 'network' is widely used and difficult to pin down. Examples in health care include terminology such as network organization, integrated delivery network, hub and spokes network, or multi-hospital network $[48,61,62,67-70]$. At the meso level, we view a network as a collection of dyadic cooperative inter-organizational ties. They are neither arms-length transactions between separated organizations nor fully integrated organizations [63,71]. Instead, they consist of a collection of legally independent organizations (i.e. nodes) connected by (multiple) cooperative inter-organizational ties [72]. Considering inter-organizational relations in their network context furthermore allows for the investigation of their intermediary role between the macro and micro level. As Borgatti and Halgin [73] put it; considering the network perspective allows for the identification of processes that determine why networks have the structures they do (e.g. the interplay between the macro and meso level) and how specific network structure lead to certain outcomes (e.g. the interplay between the meso and micro level). 


\subsection{Inter-organizational ties in health care}

Cooperative inter-organizational relations come in a variety of forms $[57,74]$. In order to influence outcomes they should however transcend mere formal agreements to collaborate and constitute actual collaborative tasks and behaviour $[64,75]$. In other words, they should involve flows of assets, information, or status from one organization to another [76]. Although several of such ties are conceivable, we review here three which are used in existing literature. These are: patient transfers, professionals' affiliations, and interlocking directorates. Together these describe a cross-section of a typical healthcare organization at the patient level, the professional's level and the board level. They can furthermore be studied in a horizontal (i.e. between providers in a similar domain) as well as a vertical (i.e. between providers in different domains) sense. However, by no means do these ties constitute an exhaustive list. Future research could identify other generalizable, healthcare-specific, inter-organizational relations able to perform the mediating role at the meso level.

\subsubsection{Patient transfers}

Patient transfers between healthcare providers have been used in pioneering papers in the field of interorganizational networks within health care [e.g. 57,77-82]. They represent a form of collaboration that is inherent to the fragmented nature of the healthcare industry in which multiple organizations treat a patient. Patient transfers have been described as a cooperative inter-organizational relation due to the fact that transferring a patient from one organization to another establishes a relation in which information and knowledge is passed from one to the other [77]. As Lomi et al. [81] describe it: "Patient sharing requires that partner hospitals commit resources to joint infrastructural investments to support relational coordination, a reliable signal of collaboration between sending and receiving hospitals." [81]. Or as Gittell and Weiss [59] put it; "To discharge patients properly requires some kind of relationships with downstream providers who will care for the patients postdischarge, both to assure that slots will be available on short notice, and to assure that once gone, patients will be in good hands." [59].

\subsubsection{Professionals' affiliations}

The second type of cooperative inter-organizational relation we propose to accompany our framework is that of professionals' affiliations. Empirical research has focused on cooperation between healthcare professionals such as medical specialists [83] but has predominantly done so within organizational boundaries. We instead propose an inter-organizational approach to this matter. In line with Dyer and Singh [52], Gittell and Weiss [59], and Westra et al. [84] we propose that interfirm knowledge sharing routines can consist of healthcare professionals who cross organizational boundaries. Such interaction between organizations, operationalized for example through sharing healthcare professionals, can foster inter-organizational learning $[59,85]$.

\subsubsection{Interlocking directorates}

The third form of inter-organizational cooperation within the healthcare domain we propose to consider at the meso level is that of interlocking directorates. Interlocking directorates refers to the practice of 'sharing' board members between organizations. It has been described as a strong predictor of strategic decisions by organizations which in turn influence an organization's profitability and serve as a vehicle to reduce external uncertainty stemming from competition for example $[68,86]$. Interlocking directorates are perceived as vehicles of communication and coordination between organizations which can influence an organization's financial sustainability and facilitate health outcomes such as the accessibility of care.

\subsection{The macro, meso, micro interplay}

Pro-competitive reforms are instruments used by policy makers to optimize the outcomes for patients, rather than a goal in itself $[87,88]$. Two distinct mechanisms underpin this effect. The first is that the behaviour of healthcare organizations drives the creation of value for patients. Rooted in the traditional neoclassical competitive logic, the assumed mechanism, in the case of pro-competitive healthcare reforms, is that competition maximises value for patients $[10,11]$. In other words, that competitive behaviour of healthcare organizations will leave patients better off than non-competition between providers. The second underlying mechanism is that the institutional context at the policy (i.e. macro) level influences the behaviour of healthcare organizations (i.e. at the meso level) $[7,89]$ and that organizations display different behaviour in response to different policy alternatives [90]. With pro-competitive healthcare reforms the assumption is that the changes in the institutional context will lead healthcare providers to actually compete with one another [44].

These mechanisms highlights that pro-competitive reforms generate positive outcomes for patients, or fail to do so, through the intermediary role of the behaviour of healthcare providers. The interplay between three distinct levels of analysis thus becomes apparent. The first of these is the policy (i.e. macro) level. It is the institutional context which dictates the rules of the game and which can be directly altered by policy reforms. The healthcare market is the second (i.e. the meso) level. Here healthcare providers can display specific behaviour, of which competing with other providers is one example. The outcome level is the third and final of these levels. It is the level at which value for patients is assessed based on dimensions such as the price, quality, and accessibility of specific services.

Both of these mechanisms have been subject to empirical research within health care. However, following the SCP approach, the intermediary meso level has been operationalized by structural market features. We will not reiterate the mixed findings of empirical studies regarding the effect of competition on price and quality outcomes (i.e. the first mechanism) described in the introduction of this paper, we do however point out that the second mechanism has also attracted academic attention. Both in and outside the US, there has been a trend towards consolidation of healthcare markets and inte- 
gration between providers subsequent to pro-competitive reforms [67,88,91,92]. Gaynor and Haas-Wilson [92] for example question whether the 'unmistakable trend of consolidation' in healthcare markets represents an efficient response to external uncertainty or attempts to gain anticompetitive advantages. While their work underlines the mechanism that pro-competitive reforms influence the healthcare market, it also highlights the reverse interplay between the meso and macro level. In related work, Gaynor and Vogt [93] and Loozen [94] have for example discussed the rationale behind, issues with, and required adaptations of anti-trust enforcement in health care.

\section{Formalisation of the framework}

In the preceding sections we have introduced a conceptual framework based on a review of academic literature regarding the interplay between macro level policy reforms, meso level healthcare markets, and micro level outcomes and the role of inter-organizational relations between healthcare organizations in healthcare markets. The framework aims to guide future research regarding pro-competitive policy reforms on patient level outcomes within the healthcare domain. This section presents several testable propositions based on this framework. The propositions focus on the interplay between the macro and meso levels, market structure and inter-organizational relations within the meso level, the meso and the micro levels, the micro and meso levels, and the micro and macro levels.

\subsection{Policy and inter-organizational relations: macro and meso}

While several studies have been conducted regarding the evolution of market structure following procompetitive policy reforms in the healthcare sector of several countries, there is scant research investigating the relation between macro level policy and the structure and evolution of cooperative inter-organizational networks. This is particularly true for research utilizing the three types of inter-organizational ties we have proposed. Yet, as our framework proposes, if the influence of procompetitive healthcare reforms is to be fully understood, this relation should be studied in more depth.

While research has shown that inter-organizational relations such as patient transfers are common in Bismarck-type healthcare systems [e.g. 78] as well as in Beveridge-type systems [e.g. 81], the effect of reforming one type of system towards the other has yet to be studied in detail. In essence, examining this interaction tests the influence of the institutional context on the structure and evolution of inter-organizational networks in healthcare. For example, the hierarchical nature of a Beveridge-type National Health System could result in hierarchically imposed patient transfers towards a specific centre of excellence. Provan [63] has shown that hospitals which are part of a larger system (i.e. a consortium) possess less strategic decision making autonomy. A similar rationale would hold for hospitals in an NHS system. Increasing organizational autonomy by reforming the sys- tem towards a more competitive, Bismark-type, system could hence alter the structure of these networks.

The same logic holds for other types of interorganizational ties. In the case of shared professionals or board members the influence of the institutional context could be even more explicit. In some countries it is illegal for professionals to be affiliated to multiple organizations [84] and the Dutch governance-code for example limits the amount positions which can be held by board members. However, two studies in the Dutch context do indicate an increase in inter-organizational cooperation based on specialists' affiliations (i.e. shared medical specialists) as well interlocking directorates following the introduction of price competition in the Dutch healthcare market [84,95]. We formalize the interaction between the institutional context at the macro level and inter-organizational networks at the meso level in the following proposition:

Proposition 1a. Pro-competitive policy reforms affect the structure of inter-organizational networks of healthcare providers.

A reverse interaction between inter-organizational networks at the meso level and policy at the macro level can be described twofold. First, based on the ongoing nature of healthcare reforms $[44,45]$. The ongoing nature of reforms suggests that policymakers can introduce additional reforms based on the response organizations have displayed to previous (pro-competitive) reforms. Second, in line with the reasoning of consolidating healthcare markets, several authors have argued that some forms of inter-organizational cooperation potentially impede effective competition $[12,84,96]$, highlighting the potential need for stricter enforcement or adaptations of existing antitrust regulations. We hence formalize the following proposition regarding the meso to macro level interaction.

Proposition 1b. The structure of inter-organizational networks of healthcare providers affects policy reform.

\subsection{Inter-organizational relations and market structure: at the meso level}

Throughout this paper we have stressed the value of inter-organizational relations at the meso level. However, our framework does not propose a singular focus on interorganizational networks. Instead, inter-organizational networks constitute an addition to structural market features at the meso level. Following the SCP approach, market structure can influence inter-organizational behaviour of providers. Likewise, inter-organizational relations can in turn influence the structure and functioning of markets. The former has received little academic attention when it comes to the influence of inter-organizational behaviour of healthcare organizations. Studies by Mascia et al. [80], Lomi and Pallotti [79], and Mascia et al. [97], all of which utilize patient transfers, form notable exceptions. These studies find that overlap in geographic and product markets (i.e. structural features of the market) influences cooperation between providers, based on which we formalize the following proposition: 
Proposition 2a. The structure of healthcare markets affects the structure of inter-organizational networks of healthcare providers.

The latter notion has discussed theoretically by Fottler et al. [57] when they describe a process to which they refer as incrementalism of inter-organizational relations'. The authors indicate that healthcare organizations typically commence inter-organizational cooperation by using cooperative ties which require less resource commitment and bear lower risks, explicitly mentioning patient transfers as an example. As the organizations reap the rewards of their cooperative inter-organizational relation, they move towards more committed and higher risk type of relations. Complete or joint ownership, hence integration which alters market structure, is the most committed type of relation described by the authors. Although healthcare executives have an important role when it comes to matters of integration [98], this process of incrementalism has, to the best of our knowledge not been tested empirically, particularly based on the three types of interorganizational relations we have proposed. Hence, we formalize the following proposition:

Proposition 2b. The structure of inter-organizational networks of healthcare providers affects the structure of healthcare markets.

\subsection{Inter-organizational relations and outcomes: meso and micro}

Perhaps the most discussed and hypothesized aspect of inter-organizational relations in healthcare is their relation to improved patient-level outcomes such as increased accessibility, higher quality, and lower costs of health services. In their seminal work, Provan and Milward [99] show for example that networks with specific network structures are more effective than others. A finding reiterated by Mascia et al. [82] in their analysis of patient transfer networks in Italy.

What constitutes an effective network structure can however vary between the different inter-organizational ties we have proposed. As can the underlying mechanisms of how these ties influence patient level outcomes. When it comes to patient transfers for example, researchers have suggested that referring patients to high volume hospitals has the potential to prevent avoidable deaths [100] by leveraging complementary resources [78]. In case the networks facilitate the flow of patients towards providers who possess the correct resources and volumes to treat patients $[78,81,82,101]$ service duplication can furthermore be avoided $[82,100]$. Researchers have shown that patient transfer networks are associated with reduced readmission rates for patients [81] but have also found suboptimal patient transfer network configurations $[101,102]$.

When it comes to shared human resources the relation to patient level outcomes is slightly more indirect. That is, through sharing such resources, organizations create channels to transfer knowledge, routines, and best-practices, thus creating learning opportunities and harnessing the potential to increase quality of care for patients. Non-healthcare research has indeed found that partner organizations capable of effectively transferring knowledge generally outperform those who are not [52]. While two Dutch studies indicate that inter-organizational learning and improving quality of care for patients are important drivers for medical professionals to be shared [84,103], other studies have indicated that medical specialists are unable to duplicate their performance from one organization to the next $[104,105]$.

Interlocking directorates can influence patient level outcomes in an even more indirect fashion. To the best of our knowledge, research regarding interlocking directorates has not been widely adopted within health care. Outside the healthcare though, researchers have suggested that interlocking directorates influence a firm's strategies, profitability, and integration $[68,86]$. Board members are hence perceived as vehicles of knowledge transfer between organizations. Their major distinction from shared professionals however is that they do not necessarily possess knowledge of the primary process within a healthcare organization but instead harness the potential to transfer knowledge related to strategic and financial processes. Despite these differences in underlying mechanisms, we formulate the following proposition regarding the influence of inter-organizational networks at the meso level on outcomes at the micro level:

Proposition 3a. The structure of inter-organizational networks of healthcare providers affects outcomes.

In line with the previous interactions we argue that the interaction between inter-organizational networks and outcomes is also bi-directional. The inverted relation is congruent with the formalization of the classical economic notion that providers will seek a competitive advantage over one another. That is, if organization A and B (at the meso level) observe that their outcomes are suboptimal, they will respond by structuring their cooperative relations in such a manner that it will improve their performance (i.e. outcomes). Research has for example reported that providers share medical specialists in order to respond to quality and volume requirements of the market [84]. Hence, we formulate the following proposition regarding this interaction;

Proposition 3b. Outcomes affect the structure of interorganizational networks of healthcare providers.

\subsection{Outcomes and policy: micro and macro}

Lastly, we have argued that policy reforms at the macro level are implemented with the aim to improve outcomes at the micro level. They are thus fundamentally driven by discontent with existing micro level outcomes produced by a healthcare system. Current pro-competitive reforms are for example primarily aimed at slowing down increasing healthcare expenditures [2], one of such micro level outcomes. While we have argued in this paper that the effect of macro level policy reform and micro level outcomes is mediated by the structure of- and inter-organizational relations within- the healthcare market, we formalize a more direct reverse interaction between patient-level outcomes 
and policy in our framework, which leads to the following proposition:

\section{Proposition 4. Outcomes affect policy reforms.}

\section{Conclusion}

Although pro-competitive reforms have been introduced in the healthcare sector of several Western countries, the academic literature lacks a consensus on whether such reforms reach their goal of maximizing patients' value for money. We have argued that this is due to two main factors. First, existing research regarding competition in healthcare has not addressed the inherently dynamic interplay between policy at the macro level, the healthcare market at the meso level, and outcomes at the micro level. Second, the healthcare market, at the meso level, has predominantly been operationalized based on its structural features, neglecting cooperative inter-organizational relations which are relevant to understand any industry but healthcare in particular. In this paper we hence formalized a conceptual framework which addresses these two shortcomings and we have identified three types of interorganizational relations relevant to the healthcare sector, namely patient transfers, professionals' affiliations, and interlocking directorates.

From the framework we have furthermore derived several propositions to guide future research regarding pro-competitive reforms in health care. Specifically, these propositions have been aimed at the interplay between macro level policy and inter-organizational relations at the meso level, market structure and inter-organizational relations within the meso level, inter-organizational relations at the meso and outcomes at the micro level and vice-versa, and outcomes at the micro level and policy at the macro level. Specifically, future empirical research could investigate the directionality of these propositions. The analysis of networks of cooperative inter-organizational relations in healthcare markets could help researchers and policymakers to understand why certain policies do or do attain intended benefits for patients.

\section{References}

[1] OECD. What Future for Health Spending? OECD Economics Department Policy Notes, No. 19; 2013. June.

[2] Toth F. Healthcare policies over the last 20 years: reforms and counter-reforms. Health Policy 2010;95:82-9.

[3] Ham C. Health care reform. British Medical Journal 1993;306:1223.

[4] Aas IM. Incentives and financing methods. Health Policy 1995;34:205-20.

[5] Cutler DM. Equality, efficiency, and market fundamentals: the dynamics of international medical-care reform. Journal of Economic Literature 2002:40:881-906.

[6] Cabiedes L, Guillén A. Adopting and adapting managed competition: health care reform in Southern Europe. Social Science \& Medicine 2001:52:1205-17.

[7] Light D. Comparative institutional response to economic policy managed competition and governmentality. Social Science \& Medicine 2001;52:1151-66.

[8] Light D. Managed competition, governmentality and institutional response in the United Kingdom. Social Science \& Medicine 2001;52:1167-81.

[9] Tuohy $\mathrm{CH}$. Reform and the politics of hybridization in mature health care states. Journal of Health Politics, Policy and Law 2012;37:611-32.
[10] Enthoven AC. The history and principles of managed competition. Health Affairs 1993:12:24-48.

[11] Porter ME. What is value in health care. New England Journal of Medicine 2010;363:2477-81.

[12] Enthoven AC. Theory and practice of managed competition in health care finance. Amsterdam, The Netherlands: Elsevier Science Publishers B.V.; 1988

[13] Dranove D, Satterthwaite MA. The industrial organization of health care markets. In: Culyer AJ, Newhouse JP, editors. Handbook of health economics. Elsevier; 2000. p. 1093-139.

[14] Porter M, Teisberg E. Redefining competition in health care. Harvard Business Review 2004:64-77.

[15] Herzlinger RE. Who killed health care? America’s \$2 trillion medical problem and the consumer-driven cure. McGraw-Hill; 2007.

[16] Arrow KJ. Uncertainty and the welfare economics of medical care. The American Economic Review 1963;53:141-9.

[17] Gaynor M, Town RJ. Competition in health care markets. National Bureau of Economic Research; 2011.

[18] Heijink R, Mosca I, Westert G. Effects of regulated competition on key outcomes of care: cataract surgeries in The Netherlands. Health Policy 2013:113:142-50.

[19] Enthoven AC, van de Ven WP. Going Dutch-managed-competition health insurance in The Netherlands. New England Journal of Medicine 2007:357:2421-3.

[20] Dranove D, Shanley M, White WD. Price and concentration in hospital markets: the switch from patient-driven to payer-driven competition. Journal of Law and Economics 1993;36:179-204.

[21] Keeler EB, Melnick G, Zwanziger J. The changing effects of competition on non-profit and for-profit hospital pricing behavior. Journal of Health Economics 1999;18:69-86

[22] Halbersma R, Mikkers M, Motchenkova E, Seinen I. Market structure and hospital-insurer bargaining in The Netherlands. European Journal of Health Economics 2011;12:589-603.

[23] Sari N. Do competition and managed care improve quality. Health Economics 2002;11:571-84

[24] Gowrisankaran G, Town RJ. Competition, payers, and hospital quality. Health Services Research 2003;38:1403-22.

[25] Rogowski J, Jain AK, Escarce JJ. Hospital competition, managed care, and mortality after hospitalization for medical conditions in California. Health Services Research 2007;42:682-705.

[26] Ikkersheim DE, Koolman X. Dutch healthcare reform: did it result in better patient experiences in hospitals? A comparison of the consumer quality index over time. BMC Health Services Research 2012;12:76

[27] Mukamel DB, Zwanziger J, Bamezai A. Hospital competition, resource allocation and quality of care. BMC Health Services Research 2002;2:10,

[28] Volpp KG, Williams SV, Waldfogel J, Silber JH, Schwartz JS, Pauly MV. Market reform in New Jersey and the effect on mortality from acute myocardial infarction. Health Services Research 2003;38:515-33.

[29] Dranove D, Shanley M, Simon C. Is hospital competition wasteful? The RAND Journal of Economics 1992;2:7-62.

[30] Enthoven AC. Consumer-choice health plan (first of two parts). Inflation and inequity in health care today: alternatives for cost control and an analysis of proposals for national health insurance. New England Journal of Medicine 1978:298-650.

[31] Luft HS, Robinson JC, Garnick DW, Maerki SC, McPhee SJ. The role of specialized clinical services in competition among hospitals. Inquiry 1986;23:83-94.

[32] Robinson JC, Luft HS. Competition and the cost of hospital care, 1972 to 1982. Journal of the American Medical Association $1987 ; 257: 3241-5$.

[33] Farley DO. Competition under fixed prices: effects on patient selection and service strategies by hemodialysis providers. Medical Care Research and Review 1996;53:330-49.

[34] Held PJ, Pauly MV. Competition and efficiency in the end stage renal disease program. Journal of Health Economics 1983;2:95-118.

[35] Kessler DP, McClellan MB. Is hospital competition socially wasteful. Quarterly Journal of Economics 2000;115:577-615.

[36] Kessler DP, Geppert JJ. The effects of competition on variation in the quality and cost of medical care. Journal of Economics \& Management Strategy 2005;14:575-89.

[37] Gaynor M, Moreno-Serra R, Propper C. Death by market power: reform, competition and patient outcomes in the National Health Service. National Bureau of Economic Research; 2010.

[38] Cooper Z, Gibbons S, Jones S, McGuire A. Does hospital competition save lives? evidence from the English NHS patient choice reforms. Economic Journal 2011;121:F228-60. 
[39] Shortell SM, Hughes EF. The effects of regulation, competition, and ownership on mortality rates among hospital inpatients. New England Journal of Medicine 1988;318:1100.

[40] Mukamel DB, Zwanziger J, Tomaszewski KJ. HMO penetration, competition, and risk-adjusted hospital mortality. Health Services Research 2001;36:1019.

[41] Propper C, Burgess S, Green K. Does competition between hospitals improve the quality of care? Hospital death rates and the NHS internal market. Journal of Public Economics 2004;88:1247-72.

[42] Porter M. Competitive strategy: techniques for analyzing industries and competitors. New York, NY: The Free Press; 1980.

[43] Bain JS. Relation of profit rate to industry concentration: American manufacturing, 1936-1940. Quarterly Journal of Economics $1951 ; 65: 293-324$.

[44] Maarse H. Markthervorming in de zorg; een analyse vanuit het perspectief van de keuzevrijheid, solidariteit, toegankelijkheid, kwaliteit en betaalbaarheid. Maastricht: Universitaire Pers Maastricht; 2011.

[45] Van de Ven WP, Schut FT. Managed competition in The Netherlands: still work-in-progress. Health Economics 2009;18:253-5.

[46] Scherer FM, Ross D. Industrial market structure and economic performance. University of Illinois at Urbana-Champaign's Academy for Entrepreneurial Leadership Historical Research Reference in Entrepreneurship; 1990.

[47] Lipczynski J, Wilson J, Goddard J. Industrial organization. Competition, strategy, policy. Pearson Education Limited; 2005.

[48] Jarillo JC. On strategic networks. Strategic Management Journa 1988:9:31-41.

[49] Schut FT. Workable competition in health care: prospects for the Dutch Design. Social Science \& Medicine 1992;35:1445-55.

[50] Marmor T, Wendt C. Conceptual frameworks for comparing healthcare politics and policy. Health Policy 2012;107:11-20.

[51] Levine S, White PE. Exchange as conceptual framework for the study of interorganizational relationships. Administrative Science Quarterly 1961;5:583-601.

[52] Dyer JH, Singh H. The relational view: cooperative strategy and sources of interorganizational competitive advantage. Academy of Management Review 1998;23:660-79.

[53] Lavie D. The competitive advantage of interconnected firms: an extension of the resource-based view. Academy of Management Review 2006;31:638-58.

[54] Brandenburger AM, Nalebuff BJ. Co-opetition. USA: Doubleday; 1996.

[55] Bengtsson M, Kock S. Coopetition in business networks-to cooperate and compete simultaneously. Industrial Marketing Management 2000;29:411-26.

[56] Van de Ven AH. On the nature, formation, and maintenance of relations among organizations. Academy of Management Review $1976 ; 1: 24-36$

[57] Fottler MD, Schermerhorn JR, Wong J, Money WH. Multiinstitutional arrangements in health care: review, analysis, and a proposal for future research. Academy of Management Review $1982 ; 7: 67-79$

[58] Provan KG, Milward HB. Do networks really work? A framework for evaluating public-sector organizational networks. Public Administration Review 2001;61:414-23.

[59] Gittell JH, Weiss L. Coordination networks within and across organizations: a multi-level framework. Journal of Management Studies 2004;41:127-53.

[60] Provan KG, Fish A, Sydow J. Interorganizational networks at the network level: a review of the empirical literature on whole networks. Journal of Management 2007;33:479-516.

[61] Bazzoli GJ, Shortell SM, Dubbs N, Chan C, Kralovec P. A taxonomy of health networks and systems: bringing order out of chaos. Health Services Research 1999;33:1683.

[62] Burns LR, Pauly MV. Integrated delivery networks: a detour on the road to integrated health care. Health Affairs 2002;21:128-43.

[63] Provan KG. Interorganizational cooperation and decision making autonomy in a consortium multihospital system. Academy of Management Review 1984;9:494-504.

[64] Wells R, Weiner BJ. Adapting a dynamic model of interorganizational cooperation to the health care sector. Medical Care Research and Review 2007;64:518-43.

[65] Gulati R, Zaheer A, Nohria N. Strategic networks. Strategic Management Journal 2000;21:203.

[66] Granovetter M. The strength of weak ties: a network theory revisited. Sociological Theory 1983;1:201-33.
[67] Luke RD, Begun JW, Pointer DD. Quasi firms: strategic interorganizational forms in the health care industry. Academy of Management Review 1989;14:9-19.

[68] Borgatti SP, Foster PC. The network paradigm in organizational research: a review and typology. Journal of Management 2003;29:991-1013.

[69] Dubbs NL, Bazzoli GJ, Shortell SM, Kralovec PD. Reexamining organizational configurations: an update, validation, and expansion of the taxonomy of health networks and systems. Health Services Research 2004;39:207-20

[70] Lega F. Strategies for multi-hospital networks: a framework. Health Services Management Research 2005;18:86-99.

[71] Thorelli HB. Networks: between markets and hierarchies. Strategic Management Journal 1986;7:37-51.

[72] Brass DJ, Galaskiewicz J, Greve HR, Tsai W. Taking stock of networks and organizations: a multilevel perspective. Academy of Management Journal 2004;47:795-817.

[73] Borgatti SP, Halgin DS. On network theory. Organization Science $2011 ; 22: 1168-81$.

[74] Barringer BR, Harrison JS. Walking a tightrope: creating value through interorganizational relationships. Journal of Management 2000;26:367-403

[75] Bazzoli GJ, Casey E, Alexander JA, Conrad DA, Shortell SM, Sofaer S, et al. Collaborative initiatives: where the rubber meets the road in community partnerships. Medical Care Research and Review 2003;60:63S-94S

[76] Gnyawali DR, Madhavan R. Cooperative networks and competitive dynamics: a strucutral embeddedness perspective. Academy of Management Review 2001;26:431-45.

[77] Iwashyna TJ, Christie JD, Kahn JM, Asch DA. Uncharted paths hos pital networks in critical care. CHEST Journal 2009;135:827-33.

[78] Iwashyna TJ, Christie JD, Moody J, Kahn JM, Asch DA. The structure of critical care transfer networks. Medical Care 2009;47:787.

[79] Lomi A, Pallotti F. Relational collaboration among spatial multipoint competitors. Social Networks 2012;34:101-11.

[80] Mascia D, Di Vincenzo F, Cicchetti A. Dynamic analysis of interhospital collaboration and competition: empiricial evidence from an Italian regional health system. Health Policy 2012;105:273-81.

[81] Lomi A, Mascia D, Vu DQ, Pallotti F, Conaldi G, Iwashyna TJ. Quality of care and interhospital collaboration: a study of patient transfers in Italy. Medical Care 2014;52:407-14

[82] Mascia D, Angeli F, Di Vincenzo F. Effect of hospital referral networks on patient readmissions. Social Science \& Medicine 2015;132:113-21.

[83] Cunningham FC, Ranmuthugala G, Plumb J, Georgiou A, Westbrook JI, Braithwaite J. Health professional networks as a vector for improving healthcare quality and safety: a systematic review. BMJ: Quality and Safety 2012;21:239-49.

[84] Westra D, Angeli F, Jatautaitè E, Carree M, Ruwaard D. Understanding specialist sharing: a mixed-method exploration in an increasingly price-competitive hospital market. Social Science \& Medicine 2016;162:133-42.

[85] Nooteboom B. Learning by interaction: absorptive capacity, cognitive distance and governance. Journal of Management and Governance 2000;4:69-92.

[86] Mizruchi MS. What do interlocks do? An analysis, critique, and assessment of research on interlocking directorates. Annual Review of Sociology 1996;22:271-98.

[87] Maarse H, Paulus A. The politics of health-care reform in The Netherlands since 2006. Health Economics, Policy and Law 2011;6:125-34.

[88] Maarse H, Jeurissen P, Ruwaard D. Results of the market-oriented reform in The Netherlands: a review. Health Economics, Policy and Law 2016:11:161-78.

[89] Van Raak A, Paulus A, Mur-Veeman I. Why do health and social care providers co-operate. Health Policy 2005;74:13-23.

[90] Lucas Jr RE. Econometric policy evaluation: a critique. CarnegieRochester conference series on public policy. Elsevier; 1976. p. 19-46.

[91] Varkevisser M, Schut FT. The impact of geographic market definition on the stringency of hospital merger control in Germany and The Netherlands. Health Economics, Policy and Law 2012;7:363-81.

[92] Gaynor M, Haas-Wilson D. Change, consolidation, and competition in health care markets. National Bureau of Economic Research; 1998.

[93] Gaynor M, Vogt WB. Antitrust and competition in health care markets. In: Culyer AJ, Newhouse JP, editors. Handbook of health economics, vol. 1. Elsevier Science B.V.; 2000. p. 1405-86 
[94] Loozen EM. Public healthcare interests require strict competition enforcement. Health Policy 2015;119:882-8.

[95] Westra D, Angeli F, Carree M, Ruwaard D. Bestuurlijke dubbelrollen: Natuurlijke bestuursstructuur of doorn in het oog van de governancecode? In: den Uijl H, van Zonneveld T, editors. Zorg voor Toezicht: de maatschappelijke betekenis van governance in de zorg. Amsterdam: Mediawerf; 2015. p. 224-32.

[96] Varkevisser M, van der Geest SA, Loozen EMH, Mosca I, Schut FT. Instellingsoverstijgende maatschappen: huidige ontwikkelingen, mogelijke gevolgen en de aanpak van eventuele mededingingsproblemen. Rotterdam: iBMG; 2013.

[97] Mascia D, Pallotti F, Angeli F. Don't stand so close to me: competitive pressures, proximity and inter-organizational collaboration. Regional Studies 2016:1-14.

[98] Alexander JA, Burns LR, Morrisey MA, Johnson V. CEO perceptions of competition and strategic response in hospital markets. Medical Care Research and Review 2001;58:162-93.

[99] Provan KG, Milward HB. A preliminary theory of network effectiveness: a comparative study of four community mental health systems. Administrative Science Quarterly 1995;40:1-33.
[100] Dudley RA, Johansen KL, Brand R, Rennie DJ, Milstein A. Selective referral to high-volume hospitals: estimating potentially avoidable deaths. Journal of the American Medical Association 2000;283:1159-66.

[101] Iwashyna TJ. The incomplete infrastructure for interhospital patient transfer. Critical Care Medicine 2012;40:2470-8.

[102] Veinot TC, Bosk EA, Unnikrishnan K, Iwashyna TJ. Revenue, relationships and routines: the social organization of acute myocardial infarction patient transfers in the United States. Social Science \& Medicine 2012;75:1800-10.

[103] Varkevisser M, Van der Geest SA, Loozen EMH. Kansen en knelpunten van regiomaatschappen. Medisch Contact 2013;1:1914-6.

[104] Huckman RS, Pisano GP. The firm specificity of individual performance: evidence from cardiac surgery. Management Science 2006;52:473-88.

[105] Westert G, Nieboer AP, Groenewegen PP. Variation in duration of hospital stay between hospitals and between doctors within hospitals. Social Science \& Medicine 1993;37:833-9. 